\title{
Intestinal Parasite Infestation in HIV Infected Patients in Tertiary Care Center
}

\author{
Dhruba Hari Chandi* (D) and Sucheta J. Lakhani \\ Department of Microbiology, SBKS Medical Institute and Research Centre, \\ Piparia - 391 760, Gujarat, India.
}

\begin{abstract}
Every year, the number of people living with HIV rises as a consequence of advanced infections and the positive effects of highly active antiretroviral therapy (HAART). Gastrointestinal involvement is common, with $90 \%$ of patients seeking treatment for gastrointestinal problems as their HIV infection progresses. Nonetheless, identifying and characterization of infectious agents is important for patient management by excluding a clinical diagnosis and determining appropriate treatment, as well as determining public healthcare policy for true pathogen prevalence and yielding epidemiological risk factors for specific infections. The aim of this study is to evaluate the prevalence of symptomatic or asymptomatic intestinal parasitic infection among HIV or AIDS patients. For this study with 80 HIV seropositive patients being recruited from various wards and the Integrated Counseling and Testing Center (ICTC) affiliated to the microbiology department. Patients with acute and chronic diarrhea with abdominal disorder were taken as symptomatic whereas patients without these clinical complaints and who came for routine investigations were taken as asymptomatic. Firstly stool samples were analyzed by macroscopically for the presence of mucus, blood, larvae, segments of tapeworm and adult worms. The consistencies of stool were also recorded such as formed, watery or soft or loose with odor and color. It was examined microscopically after macroscopically for protozoan cysts and trophozoites, helminthic ova and larvae, as wet mount preparation by saline and iodine preparation as well as formal ether concentrated. For the detection of intestinal coccidian parasites, smears were prepared from stool samples and a modified Ziel-Nelseen (MZN) stain was also performed. Stool samples with the detection of parasites were informed for treatment. The prevalence of intestinal parasite was $\mathbf{2 3 . 7 5 \%}$ with asymptomatic and symptomatic groups having a prevalence of $16.98 \%$ and $37.04 \%$ respectively. Out of total patients, $56.25 \%$ were male and $\mathbf{4 3 . 7 5 \%}$ were female. Among the male patients, 11 (13.75\%) were positive for an intestinal parasitic infection and $8(10 \%)$ were positive among females. The age distribution data revealed that the age group 21-40 years old had the highest number of intestinal parasites, followed by $41-60,61-80$, and $0-20$ years old. The most intestinal parasites were found in the young and middle-aged
\end{abstract}

*Correspondence: dhrubachandi@gmail.com; +91 9584543658

(Received: June 22, 2021; accepted: August 12, 2021)

Citation: Chandi DH, Lakhani SJ. Intestinal Parasite Infestation in HIV Infected Patients in Tertiary Care Center. J Pure Appl Microbiol. 2021;15(3):1602-1607. doi: 10.22207/JPAM.15.3.56

(C) The Author(s) 2021. Open Access. This article is distributed under the terms of the Creative Commons Attribution 4.0 International License which permits unrestricted use, sharing, distribution, and reproduction in any medium, provided you give appropriate credit to the original author(s) and the source, provide a link to the Creative Commons license, and indicate if changes were made. 
patients, according to this study. Different parasites were identified as Entamoeba histolytica, Taenia species, Ascaris lumbricoides, Cryptosporidium parvum and Isospora with one protozoan, two coccidian parasites and two helminthes. The most common parasite was Taenia species 6 (7.5\%) followed by Entamoeba histolytica $5(6.3 \%)$ and Cryptosporidium parvum $5(6.3 \%)$. Intestinal parasitic infection is not uncommon in HIV seropositive patients. This study underscores the need for early diagnosis and treatment of these intestinal parasites in both symptomatic and asymptomatic HIV patients.

Keywords: HIV/AIDS, parasites, infection

\section{INTRODUCTION}

Globally Human Immuno-Deficiency Virus / Acquired Immune Deficiency Syndrome (HIV/AIDS) is a type of common health problem ${ }^{1}$. Superimposed infection, caused by a defect in immunity, is one of the most serious health issues among HIV-positive people? .

Every year, the number of people living with HIV rises as a consequence of advance infections and the positive effects of highly active antiretroviral therapy (HAART) ${ }^{3}$. Since the onset of AIDS, clinical changes affecting the gastrointestinal system have been common, particularly diarrhoea caused by parasite infections ${ }^{4}$. Many studies showed that intestinal parasites such as Entamoeba histolytica/dispar, Giardia lamblia, Cryptosporidium species, Cyclospora cayetanensis, Isospora belli and Strongyloides stercoralis are accountable for $60-80 \%$ of infestations ${ }^{5}$. These parasitic infections play a significant role in HIV/ AIDS pathogenesis and diarrhoeal disease accept as an important role up to $50 \%$ in developing countries. Many studies have shown the impact of socioeconomic status and cultural issues on the onset of intestinal parasite infection in the general population and HIV-positive patients in particular ${ }^{3}$. Immunosuppression caused by HIV infection encourages the occurrence of many opportunistic diseases that cause high mortality, with gastroenteritis occupying a prominent position $^{7,8}$. Gastrointestinal association is common, with $90 \%$ of patients seeking treatment for gastrointestinal problems as their HIV infection progresses ${ }^{9}$. Nonetheless, identifying and characterization of infectious agents is important for patient management by excluding a clinical diagnosis and determining appropriate treatment, as well as determining public healthcare policy for true pathogen prevalence and yielding epidemiological risk factors for specific infections ${ }^{10}$. In 2012, the National AIDS Response resulted in the treatment of 2,212 patients in seven facilities with antiretroviral therapy (ART) ${ }^{11}$. The association between intestinal parasite infections and several nutritional markers has been demonstrated in numerous studies involving nutritional status, infection prevalence and intensity ${ }^{12}$. The clinical spectrum of these parasitic protozoa infections ranges from asymptomatic infection to severe infection with chronic diarrhoea, dehydration, and mal-absorption, especially in HIV positive patients ${ }^{13}$. Such co-infections have more severe clinical signs and are more difficult to treat as compared to parasite infections in otherwise healthy people ${ }^{14}$. Due to the high prevalence of parasitic intestinal diseases in people living with HIV or AIDS, many of which are opportunistic in nature and have a severe impact on patients, new research is needed to investigate the relationship between these infections and their immune responses, as well as the nutritional effects of these diseases in this population ${ }^{3}$. In this study we aim to determine the prevalence of intestinal parasite infection in HIV seropositive patients.

\section{MATERIAL AND METHODS}

This research was carried out in the parasitological section of laboratory in the department of microbiology at CCMMC, Bhilai; Durg district of Chhattisgarh state situated in Central East India. This cross-sectional study was carried on HIV patients who visit in hospitals from November 2017 to November 2020 after obtaining institutional ethical clearance. HIV seropositive patients were randomly selected for this study irrespective of whether they were symptomatic 
or asymptomatic. A sample size of 80 was used based on an ongoing larger work of PhD theses for which this study forms a part of.

Eighty(80) HIV seropositive patients were recruited from various wards and the Integrated Counseling and Testing Center (ICTC) affiliated to the microbiology department. Detail data of patients were obtained from the patients as well as from the medical record department (MRD) during the study period. After giving consent, from all symptomatic and asymptomatic HIV patients stool sample were collected. Each patient's stools were collected in a clean, dry, leak-proof, tight-lidded plastic container. Aside from obtaining the sample, the patient's name, age, sex, occupation, history of clinical manifestations, such as diarrhoea, and antibiotic and antiparasitic drug treatment history were all noted. Stool sample was process as per the standard protocol for detection of parasites by Macroscopic Examination, Microscopic Examination and Concentration technique as Formal ether concentration ${ }^{15}$.

Firstly stool sample were analyzed by macroscopically for presence of mucus, blood, larvae, segments of tapeworm and adult worms. The consistencies of stool were also recorded such as formed, watery or soft or loose with odor and color.

In the microscopic examination after macroscopically, Saline and lodine wet mount were performed for the presence of parasitic cysts, trophozoites and ova or larva as well as formal ether concentrated were also perform and examined microscopically. Modified ZiehlNeelsen (MZN) stain was also done for detection and identification of intestinal coccidians like Cryptosporidium parvum and Isospora bell $i^{15}$. Stool sample with detection of parasites were informed for treatment.

\section{RESULT}

A total of 80 stool samples were collected and tested for intestinal parasite infection in HIV-positive patients. Out of 80 HIV seropositive patients, 53 were asymptomatic and 27 were symptomatic patients. The prevalence of intestinal parasite in the study subjects was $23.75 \%$ while it was $16.98 \%$ and $37.04 \%$ in the asymptomatic and symptomatic subjects respectively (Table 1 ).

Among 80 HIV seropositive patients,
$56.25 \%$ were male and $43.75 \%$ were female. Among the male patients, 11 (13.75\%) were positive for intestinal parasitic infection and 8 $(10 \%)$ were positive among females (Table 2). The positivity ratio between male and female is 1: 1.375.

In this study HIV seropositive patient with age range from 0-80 years old were included with the mean age of $39.2 \pm 9.1$ years old [Standard Deviation (SD) 13.84]. The age group 21-40 years old had the largest age distribution, while the age group 0-20 years old had the lowest. The age distribution data revealed that the age group 2140 years old had the highest number of intestinal parasites, followed by $41-60,61-80$ and $0-20$ years old. The most intestinal parasites were found in the young and middle-aged patients, according to this studied i.e. Between 21-40 years old age group. In the age group 0-20 years old and $61-80$ years old only $2.5 \%$ of intestinal parasites were detected (Table 3).

Out of 80 samples 19 (23.75\%) were diagnosed as parasitic infection. Different parasites were identified as Entamoeba histolytica, Taenia species, Ascaris lumbricoides, Cryptosporidium parvum and Isospora with one protozoan, two coccidian parasites and two helminthes. Most common parasite was Taenia species 6(7.5\%) followed by Entamoeba histolytica 5 (6.3\%) and Cryptosporidium parvum 5 (6.3\%).

From the total number of patients, 26 were those patients with $\mathrm{CD} 4^{+} \mathrm{T}$ cell count less than 200 cells $/ \mu$ l followed by 19 were those patients with $\mathrm{CD}^{+} \mathrm{T}$ cell count $200-499$ cells/ $\mu \mathrm{l}$ and 35 were those patients with greater than or equal to 500 cells $/ \mu$ l. In this study among the patient with HIV-positive with $\mathrm{CD}^{+}{ }^{+} \mathrm{T}$ cell count $<200$ cells/ $\mu$ l had higher possibility of infestation with intestinal parasitic as compared to those with $\mathrm{CD} 4^{+} \mathrm{T}$ cell count of 200-499 and those with $\mathrm{CD}^{+}$ T cell count $>500$ (Table 4 ).

Table 1. Showing prevalence of Parasites in Asymptomatic and Symptomatic group

\begin{tabular}{lccc}
\hline Group & Total & Positive & Percentage \\
\hline Asymptomatic Group & 53 & 9 & 16.98 \\
Symptomatic Group & 27 & 10 & 37.04 \\
Total & 80 & 19 & 23.75 \\
\hline & \multicolumn{3}{c}{ www.microbiologyjournal.org }
\end{tabular}


Table 2. Distributions of HIV seropositive patients with positivity according to gender

\begin{tabular}{lcccc}
\hline Gender & $\begin{array}{c}\text { Number of } \\
\text { patient }\end{array}$ & Percentage & $\begin{array}{c}\text { Number of } \\
\text { positive }\end{array}$ & Percentage \\
\hline Male & 45 & 56.25 & 11 & 13.75 \\
Female & 35 & 43.75 & 8 & 10 \\
Total & 80 & 100 & 19 & 23.75 \\
\hline
\end{tabular}

\section{DISCUSSION}

The advent and spread of AIDS is the biggest threat to public health in modern times. In today's world, HIV infection has become a major issue. Infection is prevalent in many parts of the world, including Southeast Asia. The link between intestinal parasite diseases and the AIDS pandemic is a critical concern ${ }^{16}$. In this study the prevalence rate of intestinal parasites was $23.75 \%$ among patients who have tested positive for HIV. The study done by Rodriguez-Perez EG et a ${ }^{17}$ from Mexico showed the prevalence rate of $69 \%$, which was high when compared with this study. Another study conducted by Obateru OA et $\mathrm{al}^{5}$ in 2016 from Nigeria showed prevalence rate of intestinal parasites was $68.5 \%$ which was very high when compared to this study. Nkenfou $\mathrm{CN}$ et al ${ }^{18}$ from Cameroon reported the prevalence of intestinal parasitic infection of $59.52 \%$. Teklemariam $Z$ et $\mathrm{al}^{19}$ from Ethiopia reported the prevalence of intestinal parasitic infection rate of $33.7 \%$, which was also showed higher than this study. Intestinal parasite infections have been observed in HIVpositive patients from various locations of India.
Gupta K et $a^{20}$ from New Delhi, India reported in HIV-positive patients, the prevalence of intestinal parasite infestation was found as $59.3 \%$ which was higher than this study. Mathur MK et al ${ }^{21}$ from Jamnagar, India also showed the prevalence rate of $50.36 \%$. Another study of Rao RP et a $\left.\right|^{14}$ in 2015 from Mangalore, India reported $49 \%$ of parasitic infection in HIV seropositive patients. Kaniyarakkal $V$ et $a^{22}$ from South India (Kozhikode) reported 9\% as prevalence of parasitic infection which was very less as compared to this study. A study conducted by Swathirajan CR et al ${ }^{23}$ from Tamil Nadu, India intestinal parasite infections are common among HIV/AIDS patients was $23.4 \%$ which showed similar with this study. Another study of Ghoshal $U$ et $\mathrm{al}^{24}$ in Lucknow, Uttar Pradesh, India prevalence of intestinal parasitic infection was reported as $57.81 \%$, which was also high when compared to this study. There is a discrepancy in the prevalence of intestinal parasitic infestations in HIV seropositive individuals when compared to studies conducted by different authors from India or elsewhere, which could be related to differences in geographical distribution of parasites, hygienic

Table 3. Distributions of HIV seropositive patients with positivity according to age

\begin{tabular}{lcccc}
\hline Age & $\begin{array}{c}\text { Number of } \\
\text { patient }\end{array}$ & Percentage & $\begin{array}{c}\text { Number of } \\
\text { positive }\end{array}$ & Percentage \\
\hline $0-20$ & 2 & 2.5 & 2 & 2.5 \\
$21-40$ & 48 & 60.0 & 12 & 15 \\
$41-60$ & 23 & 28.8 & 3 & 3.75 \\
$61-80$ & 7 & 8.8 & 2 & 2.5 \\
Total & 80 & 100.0 & 19 & 23.75 \\
\hline
\end{tabular}

Table 4. Showing parasitic infection with associating $\mathrm{CD} 4^{+} \mathrm{T}$ cell count among HIV seropositive patients

\begin{tabular}{|c|c|c|c|c|}
\hline $\begin{array}{l}\text { CD4 }{ }^{+} \text {T Cell } \\
\text { count (cells/ } \mu \text { l) }\end{array}$ & $N=80$ & $\begin{array}{c}\text { Intestinal } \\
\text { parasites } N=19\end{array}$ & $\begin{array}{l}\text { Odd ratio } \\
(95 \% \mathrm{Cl})\end{array}$ & $p$-value \\
\hline$<200$ & 26 & 5 & & \\
\hline $200-499$ & 19 & 6 & 0.317 & 0.0716 \\
\hline$>500$ & 35 & 8 & & \\
\hline
\end{tabular}


habits and personal hygiene. Other reasons for the disparity in prevalence could include various immunological status cases and different stool processing methods. Patients may be infected with various intestinal parasites as a result of poor sanitation.

In this study mean age was $39.2 \pm 9.1$ years with the maximum age of 21-40 years which is similar to the study conducted by Rao RP et al ${ }^{14}$ and Swathirajan CR et al..$^{23}$ This may be due to the effect of ageing on weakened immune system that comes with status of HIV.

Male (13.75\%) showed higher prevalence as compare to female (10\%) which is comparable to the many studies as conducted by Swathirajan $\mathrm{CR}$ et $\mathrm{al}^{23}$ and Gupta $\mathrm{K}$ et $\mathrm{al}^{20}$. Various researches from various parts of India also revealed a larger proportion of males in the HIV-infected population. This male preponderance may be related to men's proclivity to relocate for job, as well as their increased exposure to promiscuous and risky sex ${ }^{22}$. In this study the most common parasite was Taenia spp followed by Entamoeba histolytica, Cryptosporidium parvum was found in $23.8 \%$ of HIV seropositive patients. Carried out with varying results, some have similar results while others different to the finding in our study. In Brazil, Amancio FA et al $^{3}$ in the year 2012 showed Entamoeba was the most common parasite and followed by Giardia lamblia, Blastocystis hominis, Endolimax nana and Ascaris lumbricoides. In another study Obateru OA et $\mathrm{al}^{5}$ reported prevalence of Cryptosporidium spp (55.0\%) as most common isolated parasite. Rao $\mathrm{RP}^{16}$ also reported Cryptosporidium spp as most common parasites followed by Isospora belli, Cyclospora, Microsporidia, Entamoeba histolytica, Hookworm. Swathirajan CR et $\mathrm{a}^{23}$ showed Cryptosporidium as a most commonly observed parasites and followed by Cystoisospora belli, Cyclospora spp. Studies from various parts of the world indicate similar rates of incidence with major regional differences. All HIV-positive patients' stools should be extensively analysed to identify intestinal infections so that adequate management can be implemented. The study showed prevalence of intestinal parasites was highly significant in HIV-positive patients with $C D 4^{+} T$ cell count $<200$ cells $/ \mu$ l had high possibility of increased parasitic infection $(P<0.05)$ as compared to patients with
$\mathrm{CD}^{+} \mathrm{T}$ cell count of $>200$. This report also showed as similar to many other study as carried out by Babatunde et $\mathrm{al}^{13}$, Assefa et $\mathrm{al}^{25}$ and Wiwanitkit et $\mathrm{al}^{26}$. Therefore, all these findings suggested that immunity plays an important role in the survival and development of intestinal parasites in HIVpositive individuals.

\section{CONCLUSION}

This study showed the prevalence of intestinal parasite was $23.75 \%$ with asymptomatic and symptomatic groups having a prevalence of $16.98 \%$ and $37.04 \%$ respectively. Taenia species was the most common parasite found in HIV patients followed by Cryptosporidium parvum and Entamoeba histolytica. The finding from our study underscores the need for early diagnosis and treatment of these intestinal parasites both in symptomatic and asymptomatic HIV patients as early as possible. This will aid clinicians in developing suitable patient treatment methods.

\section{ACKNOWLEDGMENTS}

We are grateful to our representative institutes for providing the support to complete this work.

\section{CONFLICT OF INTEREST}

The authors declare that there is no conflict of interest.

\section{AUTHORS' CONTRIBUTION}

All authors listed have made a substantial, direct and intellectual contribution to the work, and approved it for publication.

\section{FUNDING}

None.

\section{DATA AVAILABILITY}

All datasets generated or analyzed during this study are included in the manuscript.

\section{ETHICS STATEMENT}

Not applicable.

\section{REFERENCES}

1. Kalling LO. The first postmodern pandemic: 25 years of HIV/AIDS. J Inter Med. 2008;263(3):218-243. doi: 10.1111/j.1365-2796.2007.01910.x 
2. Wiwanitkit V. Intestinal parasite infestation in HIV infected patients. Curr HIV Res. 2006; 4(1):87-96. doi: $10.2174 / 157016206775197682$

3. Joint United Nations Programme on HIV/AIDS., World Health Organization. 2008 report on the global AIDS epidemic. World Health Organization; 2008.

4. Amancio FA, Pascotto VM, Souza LR, Calvi SA, Pereira PC. Intestinal parasitic infections in HIV/ AIDS patients: epidemiological, nutritional and immunological aspects. J Venom Anim Toxins Incl Trop Dis. 2012;18(2):225-235. doi: 10.1590/S167891992012000200013

5. Bolinger RC, Quinn TC. Tropical diseases in the HIVinfectedtraveller. In: Broder S, Merigan Jr, Bolognesi D, editors. Textbook of aids medicine $2^{\text {nd }}$ ed. New York: Williams \& Williams; 1994:311-22.

6. Obateru OA, Bojuwoye BJ, Olokoba AB, Fadeyi A, Fowotade A, Olokoba LB. Prevalence of intestinal parasites in newly diagnosed HIV/AIDS patients in Ilorin, Nigeria. Alexandria Journal of Medicine. 2017;53(2):111-116. doi: 10.1016/j.ajme.2016.04.001

7. Konaté $A$, Minta $D$, Diarra $M$, Dolo $A$, Dembele $M$ Diarra B, Maiga MY, Traore HA, Doumbo O. Digestive parasitosis during AIDS diarrhea. Bull Soc Pathol Exot. 2005; 98 (1): 33-5.

8. Develoux M, Enache-Angoulvant A, Hennequin C, et al. Prevalence des infections opportunistes digestives parasitaires a' Kinshasa(Republique Demogratique du Congo), Resultats dune enquete preliminaire chez 50 patients au stade SIDA. Med Trop. 2007;67(2):145-148.

9. Ilboudo D, Sanou J, Traore LK. Parasitoses digestives et infection par le virus de limmuno-deficience humaine a Ouagadougou. Medecine d'Afrique Noire. 1997;44(2):69-72.

10. Bastard M, Soulinphumy K, Phimmasone $P$, et al. Women experience a better long-term immune recovery and a better survival on HAART in Lao People's Democratic Republic. BMC Infect Dis. 2013;13:27. doi: 10.1186/1471-2334-13-27

11. UNAIDS. UNAIDS report on the global AIDS epidemic 2013. 2013. http://www.unaids.org/en/media/unaids/ contentassets/documents/epidemiology/2013/ gr2013/UNAIDS_Global_Report_2013_en.pdf. Accessed 2013 Sep 24.

12. Carvalho-Costa FA, Goncalves AQ, Lassance SL, Silva Neto LM, Salmazo CAA, Boia MN. Giardia lamblia and other intestinal parasitic infections and their relationships with nutritional status in children in Brazilian Amazon. Rev Inst Med Trop Sao Paulo. 2007;49(3):147-153. doi: 10.1590/S003646652007000300003

13. Babatunde SK, Salami AK, Fabiyi JP, Agbede OO, Desalu OO. Prevalence of intestinal parasitic infestation in HIV seropositive and seronegative patients in llorin. Nigeria Annals of African Medicine. 2010;9(3):123-128. doi: 10.4103/1596-3519.68356

14. Corbett EL, Steketee RW, ter Kuile FO, Latif AS, Kamali A, Hayes RJ. HIV-1/ AIDS and the control of other infectious diseases in Africa. Lancet. 2002;359(9324):2177-2187. doi: 10.1016/S01406736(02)09095-5
15. Cheesbrough M. District laboratory practice in tropical countries. $2^{\text {nd }}$ edition updated. Cambridge University Press; 2009:183-191.

16. Rao RP. Study of opportunistic intestinal parasitic infections in HIV seropositive patients at a tertiary care teaching hospital in Karnataka, India. Int J Contemp Med Res. 2016;3(8):2219-2222.

17. Rodriguez-Perez EG, Arce-Mendoza AY, MontesZapata El, Limon A, Rodriguez LE, EscandonVargas K. Opportunistic intestinal parasites in immunocompromised patients from a tertiary hospital in Monterrey, Mexico. Le infezioni in Medicina: Rivista Periodica di Eziologia, Epidemiologia, Diagnostica, Clinica e Terapia Delle Patologie Infettive. 2019;27(2):168-174.

18. Nkenfou CN, Nana CT, Payne VK. Intestinal parasitic infections in HIV infected and non-infected patients in a low HIV prevalence region, West-Cameroon. PLoS One. 2013;8(2):e57914. doi: 10.1371/journal. pone.0057914

19. Teklemariam Z, Abate D, Mitiku H, Dessie Y. Prevalence of intestinal parasitic infection among HIV positive persons who are naive and on antiretroviral treatment in Hiwot Fana Specialized University Hospital, Eastern Ethiopia. Int Sch Res Notices. 2013;2013:324329. doi: $10.1155 / 2013 / 324329$

20. Gupta K, Bala M, Deb M, Muralidhar S, Sharma DK. Prevalence of intestinal parasitic infections in HIVinfected individuals and their relationship with immune status. Indian J Med Microbiol. 2013;31(2):161-165. doi: 10.4103/0255-0857.115247

21. Mathur MK, Verma AK, Makwana GE, Sinha M. Study of opportunistic intestinal parasitic infections in HIV/ AIDS patients. J Glob Infect Dis. 2013;5(4):164-167. doi: 10.4103/0974-777X.122012

22. Kaniyarakkal V, Mundangalam N, Moorkoth AP, Mathew S. Intestinal parasite profile in the stool of HIV positive patients in relation to immune status and comparison of various diagnostic techniques with special reference to Cryptosporidium at a tertiary care hospital in South India. Adv Med. 2016;2016:3564359. doi: 10.1155/2016/3564359

23. Swathirajan CR, Vignesh R, Pradeep A, Solomon SS, Solomon S, Balakrishnan P. Occurrence of enteric parasitic infections among HIV-infected individuals and its relation to CD4 T-cell counts with a special emphasis on coccidian parasites at a tertiary care centre in South India. Indian J Med Microbiol. 2017;35(1):37-40. doi: 10.4103/ijmm.IJMM_16_164

24. Ghoshal U, Jain V, Tejan N, et al. A road less travelled: Clinical comparison of HIV seropositive and seronegative patients with cystoisosporiasis-An 11year experience from a tertiary care centre in Northern India. Indian J Med Microbiol. 2018;36(4):508-512. doi: 10.4103/ijmm.IJMM_18_99

25. Assefa S, Erko B, Medhen G, Assefa Z, Shimeli T. Intestinal parasitic infection in relation to HIV, AIDS status, diarrhoea and CD4 cell-count. BMC Inf Dis. 2009;9:155. doi: 10.1186/1471-2334-9-155

26. Wiwanitkit V. Intestinal parasitic infections in Thai HIVinfected patients with different immunity status. $B M C$ Gastroenterol. 2001;1:3. doi: 10.1186/1471-230x-1-3 